Check for updates

Cite this: RSC Adv., 2017, 7, 29481

Received 19th April 2017 Accepted 31st May 2017

DOI: $10.1039 / c 7 r a 04388 k$

rsc.li/rsc-advances

\section{Synthesis and electrochemical performance of $\mathrm{NaV}_{6} \mathrm{O}_{15}$ microflowers for lithium and sodium ion batteries $\dagger$}

\begin{abstract}
Fang Hu, (D) ${ }^{a}$ Wei Jiang, ${ }^{a}$ Yidi Dong, ${ }^{a}$ Xiaoyong Lai, (D) ${ }^{b} \mathrm{Li} \mathrm{Xiao}^{\mathrm{a}}$ and Xiang Wu ${ }^{\star a}$
Hierarchical $\mathrm{NaV}_{6} \mathrm{O}_{15}$ flower-like structures were successfully synthesized via a facile hydrothermal reaction combined with subsequent thermal transformation. The as-prepared $\mathrm{NaV}_{6} \mathrm{O}_{15}$ microflowers are composed of many nanoneedles with a width of about $200 \mathrm{~nm}$ and a length of several micrometers. The electrochemical performance of $\mathrm{NaV}_{6} \mathrm{O}_{15}$ microflowers as cathodes for both lithium and sodium ion batteries are investigated. High first discharge capacities of $255 \mathrm{~mA} \mathrm{~h} \mathrm{~g}^{-1}\left(\mathrm{vs}^{\mathrm{L}} \mathrm{Li}^{+} / \mathrm{Li}\right)$ and $130 \mathrm{~mA} \mathrm{~h} \mathrm{~g}^{-1}$ (vs. $\mathrm{Na}^{+} / \mathrm{Na}$ ) are observed and the capacity retention reaches $105 \%$ and $64 \%$ after 50 cycles under $4-1.5 \mathrm{~V}$ at a current density of $100 \mathrm{~mA} \mathrm{~g}^{-1}$ and $50 \mathrm{~mA} \mathrm{~g}^{-1}$, respectively. High lithium/sodium ion diffusion coefficients play an important role in improving the electrochemical performance of $\mathrm{NaV}_{6} \mathrm{O}_{15}$ microflowers.
\end{abstract}

\section{Introduction}

Recently, there has been increasing interest in rechargeable lithium-ion batteries (LIBs) and sodium-ion batteries (NIBs) because of their inherent advantages such as high specific energy density, long cycle life as well as environmental benignity. ${ }^{1-8}$ Especially, due to abundant sodium resources and potential low cost, NIBs have attracted much interest as an alternative to LIBs in large scale energy storage systems ${ }^{9,10}$ However, $\mathrm{Na}^{+}$has a larger size $(1.06 \AA)$ than that of $\mathrm{Li}^{+}(0.76 \AA)$, which makes it difficult for sodium ions to quickly insert/extract from the host materials. ${ }^{11}$ As a result, most common electrode materials for LIBs are unsuitable to accommodate sodium ions. ${ }^{\mathbf{1 2 - 1 5}}$ Therefore, it is of great importance to develop new electrode materials for both LIBs and SIBs.

Vanadium oxide possesses good reactive activity because of its variable oxidation states from +5 in $\mathrm{V}_{2} \mathrm{O}_{5}$ to +2 in VO. Especially, $\mathrm{V}_{2} \mathrm{O}_{5}$ could present various phase transformations during $\mathrm{Li}^{+} / \mathrm{Na}^{+}$ intercalation/deintercalation process. For different intercalated amounts of $\mathrm{Li}^{+} / \mathrm{Na}^{+}$, the theoretical capacities is up to $442 \mathrm{~mA} \mathrm{~h}$ $\mathrm{g}^{-1}$ and $236 \mathrm{~mA} \mathrm{~h} \mathrm{~g}{ }^{-1}$ for $\mathrm{Li}_{3} \mathrm{~V}_{2} \mathrm{O}_{5}$ and $\mathrm{Na}_{2} \mathrm{~V}_{2} \mathrm{O}_{5}$, respectively. However, $\mathrm{Li}_{x} \mathrm{~V}_{2} \mathrm{O}_{5}$ or $\mathrm{Na}_{x} \mathrm{~V}_{2} \mathrm{O}_{5}$ with an intercalated amount $x>1$ suffers a significant capacity loss during $\mathrm{Li}^{+} / \mathrm{Na}^{+}$intercalation/ deintercalation process, leading to a poor cycling performance. ${ }^{16,17}$ A possible strategy is to introduce second metal

${ }^{a}$ School of Materials Science and Engineering, Shenyang University of Technology, Shenyang110870, P. R. China.E-mail:wuxiang05@163.com; wuxiang05@sut.edu.cn ${ }^{b}$ State Key Laboratory of High-efficiency Utilization of Coal and Green Chemical Engineering, College of Chemistry and Chemical Engineering, Ningxia University, Yinchuan 750021, P. R. China

† Electronic supplementary information (ESI) available. See DOI: 10.1039/c7ra04388k cations, such as $\mathrm{Na}^{+}$and $\mathrm{NH}_{4}{ }^{+}$, into $\mathrm{V}_{2} \mathrm{O}_{5}$ interlayer, which could support $\mathrm{V}_{2} \mathrm{O}_{5}$ layers as "pillars" and generate a fast $\mathrm{Li}^{+} / \mathrm{Na}^{+}$diffusion path. ${ }^{18-20}$ At present, many types of synthesis methods for $\mathrm{NaV}_{6} \mathrm{O}_{15}\left(\beta-\mathrm{Na}_{0.33} \mathrm{~V}_{2} \mathrm{O}_{5}\right)$, such as solid-state reaction, ${ }^{21}$ sol-gel method $^{22}$ and hydrothermal method, ${ }^{23,24}$ have been attempted to improve its electrochemical performances. Among various morphologies of $\mathrm{NaV}_{6} \mathrm{O}_{15}$ structures, nanosheets, ${ }^{25}$ microspheres ${ }^{26}$ and nanoflakes, ${ }^{27}$ can improve electrochemical performance of the batteries further. For example, Lu et al. reported hydrothermal synthesis of $\beta-\mathrm{Na}_{0.33} \mathrm{~V}_{2} \mathrm{O}_{5}$ nanosheets, which exhibited a discharge capacity of $258 \mathrm{~mA} \mathrm{~h} \mathrm{~g}^{-1}$ at the current density of $150 \mathrm{~mA} \mathrm{~g}^{-1}$ and the capacity retention of $70.2 \%$ after 50 cycles. ${ }^{25}$ Wang and his coworkers prepared $\beta-\mathrm{Na}_{0.33} \mathrm{~V}_{2} \mathrm{O}_{5}$ nanorods, which delivered desirable discharge capacity of $223.9 \mathrm{~mA} \mathrm{~h} \mathrm{~g}^{-1}$ at $60 \mathrm{~mA} \mathrm{~g}^{-1}$ with high capacity retention of $81.3 \%$ after 50 cycles. $^{28}$ Jiang's group obtained $\mathrm{NaV}_{6} \mathrm{O}_{15}$ nanoplates with a discharge capacity of 116 $\mathrm{mA} \mathrm{h} \mathrm{g}{ }^{-1}\left(v s . \mathrm{Na}^{+} / \mathrm{Na}\right)$ and a cycle retention of $55 \%$ after 30 cycles at the current density of $50 \mathrm{~mA} \mathrm{~g}^{-1} .^{29}$

Herein, we report novel hierarchical $\mathrm{NaV}_{6} \mathrm{O}_{15}$ microflowers synthesized by a facile hydrothermal reaction combined with subsequent thermal transformation. Electrochemical properties of $\mathrm{NaV}_{6} \mathrm{O}_{15}$ microflowers as cathodes for both lithium and sodium ion batteries are investigated. High first discharge capacity of $255 \mathrm{~mA} \mathrm{~h} \mathrm{~g}^{-1}\left(v s . \mathrm{Li}^{+} / \mathrm{Li}\right)$ and $130 \mathrm{~mA} \mathrm{~h} \mathrm{~g}^{-1}\left(v s . \mathrm{Na}^{+} / \mathrm{Na}\right)$ are observed and capacity retentions reach $105 \%$ and $64 \%$ after 50 cycles under $4-1.5 \mathrm{~V}$ at the current density of $100 \mathrm{~mA} \mathrm{~g}^{-1}$ and $50 \mathrm{~mA} \mathrm{~g}^{-1}$, respectively. More importantly, Li/Na ion diffusion coefficients of $\mathrm{NaV}_{6} \mathrm{O}_{15}$ cathode material is proposed and verified.

\section{Experimental}

All the reagents were of analytical grade and used without further purification. In a typical procedure, $0.24 \mathrm{~g} \mathrm{NaOH}$, 
$0.234 \mathrm{~g} \mathrm{NH} \mathrm{NO}_{3}$ and $0.053 \mathrm{~g} \mathrm{Na}_{2} \mathrm{CO}_{3}$ were added together to a beaker with $50 \mathrm{~mL}$ of distilled water and the solution was stirred at $90{ }^{\circ} \mathrm{C}$ for $20 \mathrm{~min}$. Then, put the beaker into cool water. $1 \mathrm{~mL} \mathrm{3 \%} \mathrm{H}_{2} \mathrm{O}_{2}$ was dissolved in the solution and stirred about 2 min. The solution was adjusted to $\mathrm{pH} \approx 2$ by the titration of $2 \mathrm{~mol} \mathrm{~L}^{-1} \mathrm{HCl}$ and kept for stirring about $30 \mathrm{~min}$. Finally, the orange solution was thrown into a $50 \mathrm{~mL}$ autoclave and subjected to hydrothermal treatment at $200{ }^{\circ} \mathrm{C}$ for $24 \mathrm{~h}$. And then, the autoclave was naturally cooled down and yellow precipitates were collected, followed with wash with distilled water and alcohol for several times, and finally dried at $110{ }^{\circ} \mathrm{C}$. The resultant product was heated in air atmosphere at $400{ }^{\circ} \mathrm{C}$ for $4 \mathrm{~h}$ with an increasing rate of $3{ }^{\circ} \mathrm{C} \mathrm{min}^{-1}$.

The powder X-ray diffraction (XRD) patterns were obtained by an XRD-7000 diffractometer attached with $\mathrm{Cu} \mathrm{K} \alpha$ radiation. The scan step was $6^{\circ} \mathrm{min}^{-1}$ and the tube current and voltage were $30 \mathrm{~mA}$ and $40 \mathrm{kV}$, respectively. Scanning electron microscope (SEM) images were recorded by a JSM-6700F, operated at $5.0 \mathrm{kV}$. Transmission electron microscope (TEM) images were obtained by an FEI Tecnai G2. The nitrogen adsorptiondesorption isotherms at the temperature of liquid nitrogen (77 K) were measured on VSorb 4800P Surface Area and Pore Porosimetry Analyzer (Gold Spectrum Technology Co., Ltd., China) with prior degassing under vacuum for $4 \mathrm{~h}$ at $200{ }^{\circ} \mathrm{C}$. Total pore volumes were determined using the adsorbed volume at a relative pressure of 0.99. The multi-point BrunauerEmmett-Teller (BET) surface area was estimated from the relative pressure range from 0.05 to 0.2 . The pore size distribution of all the materials was analyzed from the desorption isotherm using the Barrett-Joyner-Halenda (BJH) method.

Electrochemical tests were performed by using a coin battery cell, where a metallic lithium foil was used as the anode electrode. $\mathrm{NaV}_{6} \mathrm{O}_{15}$ active material $(80 \%$, mass fraction) were blended with acetylene black (10\%, mass fraction) and polyvinylidenefluoride (PVDF, 10\%, mass fraction). The resultant slurry was pasted on an $\mathrm{Al}$ foil as cathode electrode and then dried in a vacuum oven. Each electrode $\left(8 \times 8 \mathrm{~mm}^{2}\right)$ contain $2 \mathrm{mg}$ of active material. $1 \mathrm{~mol} \mathrm{~L}^{-1}$ lithium hexafluorophosphate $\left(\mathrm{LiPF}_{6}\right)$ dissolved in ethylene carbonate (EC), dimethyl carbonate (DMC) and ethyl methyl carbonate (EMC) (EC : DMC : EMC = 1: 1: 8, by v/v ratio) was used as electrolyte. For Na coin cells, the electrolyte was $1 \mathrm{~mol} \mathrm{~L}^{-1} \mathrm{NaClO}_{4}$ dissolved in a solvent mixture of ethylene carbonate (EC) and propylene carbonate (PC) $(1: 1 \mathrm{v} / \mathrm{v})$ and 5\% FEC. Galvanostatic chargedischarge cycling was carried out with an automatic battery tester (Land-2100, China) in the voltage window of 1.5-4.0 V. Cyclic voltammetry was performed with a VSP multichannel potentiostatic-galvanostatic system (Bio-Logic) at a scanning rate of $0.05,0.1,0.15,0.2,0.25$ and $0.3 \mathrm{mV} \mathrm{s}^{-1}$, respectively.

\section{Results and discussion}

XRD patterns of the as-synthesized precursor and resultant $\mathrm{NaV}_{6} \mathrm{O}_{15}$ product are showed in Fig. 1, respectively. The diffraction peaks of the as-synthesized precursor could be well indexed to $\mathrm{HNaV}_{6} \mathrm{O}_{16} \cdot 4 \mathrm{H}_{2} \mathrm{O}$ phase (JCPDS no. 49-0996) except for an unknown diffraction peak at about $2 \theta=26.9^{\circ}$. After

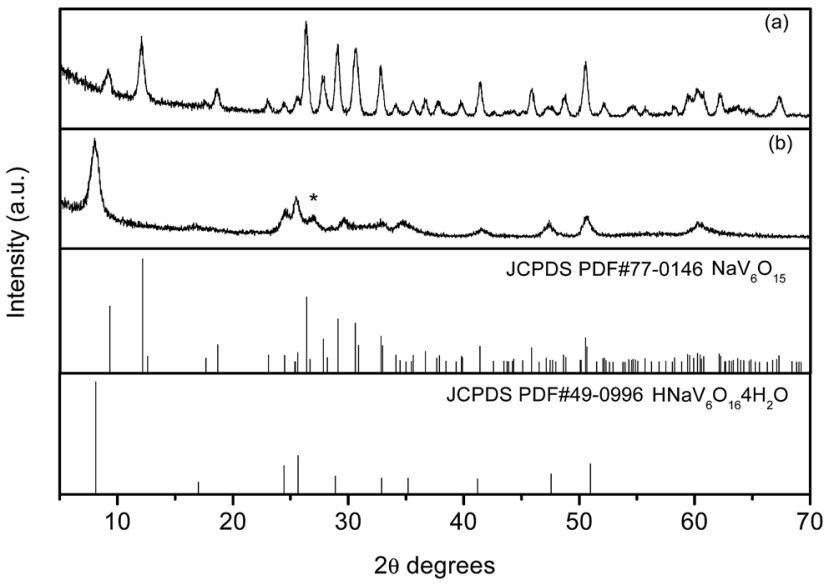

Fig. 1 XRD patterns of the as-synthesized precursor and $\mathrm{NaV}_{6} \mathrm{O}_{15}$ products

heated at $400{ }^{\circ} \mathrm{C}$, all the peaks can be well indexed to monoclinic layered $\mathrm{NaV}_{6} \mathrm{O}_{15}$ phase (JCPDS No. 24-1155), and no other impurities are detected.

General SEM images of $\mathrm{HNaV}_{6} \mathrm{O}_{16} \cdot 4 \mathrm{H}_{2} \mathrm{O}$ and $\mathrm{NaV}_{6} \mathrm{O}_{15}$ samples are shown in Fig. $2 \mathrm{a}$. $\mathrm{HNaV}_{6} \mathrm{O}_{16} \cdot 4 \mathrm{H}_{2} \mathrm{O}$ are mainly some microflowers with a diameter of about $5 \mu \mathrm{m}$. High magnification SEM images in Fig. $2 b$ shows the microflowers are composed of some nanobelts with a width of about $100 \mathrm{~nm}$ and a length of several micrometers. Fig. $2 \mathrm{c}$ and d show SEM images of $\mathrm{NaV}_{6} \mathrm{O}_{15}$ sample, which reveal that the nanobelts are melt to nanoneedles-like with a width of about $200 \mathrm{~nm}$. After calcined at $500{ }^{\circ} \mathrm{C}, \mathrm{NaV}_{6} \mathrm{O}_{15}$ microflowers are melted further to microcrystals with the size of about $1 \mu \mathrm{m}$ (Fig. S1†). $\mathrm{NaV}_{6} \mathrm{O}_{15}$ microflowers are further investigated by TEM as shown in Fig. 3. The distance between the neighboring fringes is about $0.364 \mathrm{~nm}$, which is consistent with that of the (004) plane of monoclinic layered $\mathrm{NaV}_{6} \mathrm{O}_{15}$. The mappings of different elements from $\mathrm{NaV}_{6} \mathrm{O}_{15}$ microflowers are shown in Fig. 3c. It shows that $\mathrm{Na}, \mathrm{V}$ and $\mathrm{O}$ elements are all uniformly distributed.

Nitrogen adsorption-desorption isotherms and the corresponding pore size distribution curves of $\mathrm{NaV}_{6} \mathrm{O}_{15}$ microflowers is shown in Fig. 4. The isothermal curve is of typical IV type, which indicates the porous characteristic of $\mathrm{NaV}_{6} \mathrm{O}_{15}$ microflowers. According to multi-point BET method, a high specific surface area of $54 \mathrm{~m}^{2} \mathrm{~g}^{-1}$ is achieved with an average pore size of $6.4 \mathrm{~nm}$ and a large pore volume of $0.15 \mathrm{~cm}^{3} \mathrm{~g}^{-1}$. It is well known that nanoscale materials with high surface area can decreases effective diffusion path and increases surface area for insertion and extraction of $\mathrm{Li}^{+} / \mathrm{Na}^{+}$, all of which are beneficial to the battery performance. ${ }^{30,31}$

Galvanostatic charge-discharge profiles of $\mathrm{HNaV}_{6} \mathrm{O}_{16} \cdot 4 \mathrm{H}_{2} \mathrm{O}$ and $\mathrm{NaV}_{6} \mathrm{O}_{15}$ microflowers are examined at a current density of $100 \mathrm{~mA} \mathrm{~g}^{-1}$ with $\mathrm{Li}$ in the voltage range from $4 \mathrm{~V}$ to $1.5 \mathrm{~V}$, as presented in Fig. 5a. It can be observed that $\mathrm{HNaV}_{6} \mathrm{O}_{16} \cdot 4 \mathrm{H}_{2} \mathrm{O}$ microflowers electrode presents almost no electrochemical performance. $\mathrm{NaV}_{6} \mathrm{O}_{15}$ microflowers give a high discharge capacity of $255 \mathrm{~mA} \mathrm{~h} \mathrm{~g}^{-1}$, which is larger than that of $\mathrm{NaV}_{6} \mathrm{O}_{15}$ powders calcined at $500{ }^{\circ} \mathrm{C}$ (Fig. S2a $\dagger$ ). From the cyclic 

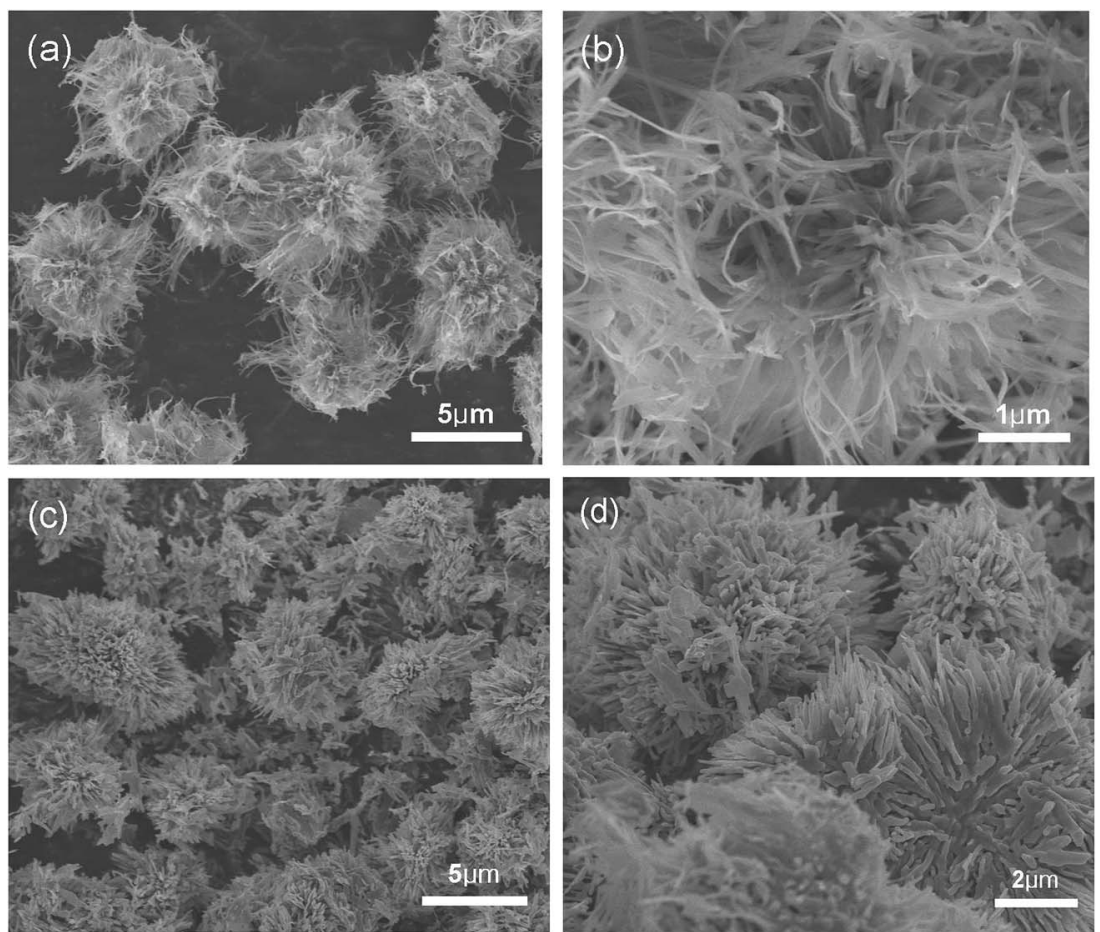

Fig. 2 SEM images of $\mathrm{HNaV}_{6} \mathrm{O}_{16} \cdot 4 \mathrm{H}_{2} \mathrm{O}$ (a and b) and $\mathrm{NaV}_{6} \mathrm{O}_{15}$ samples (c and d).
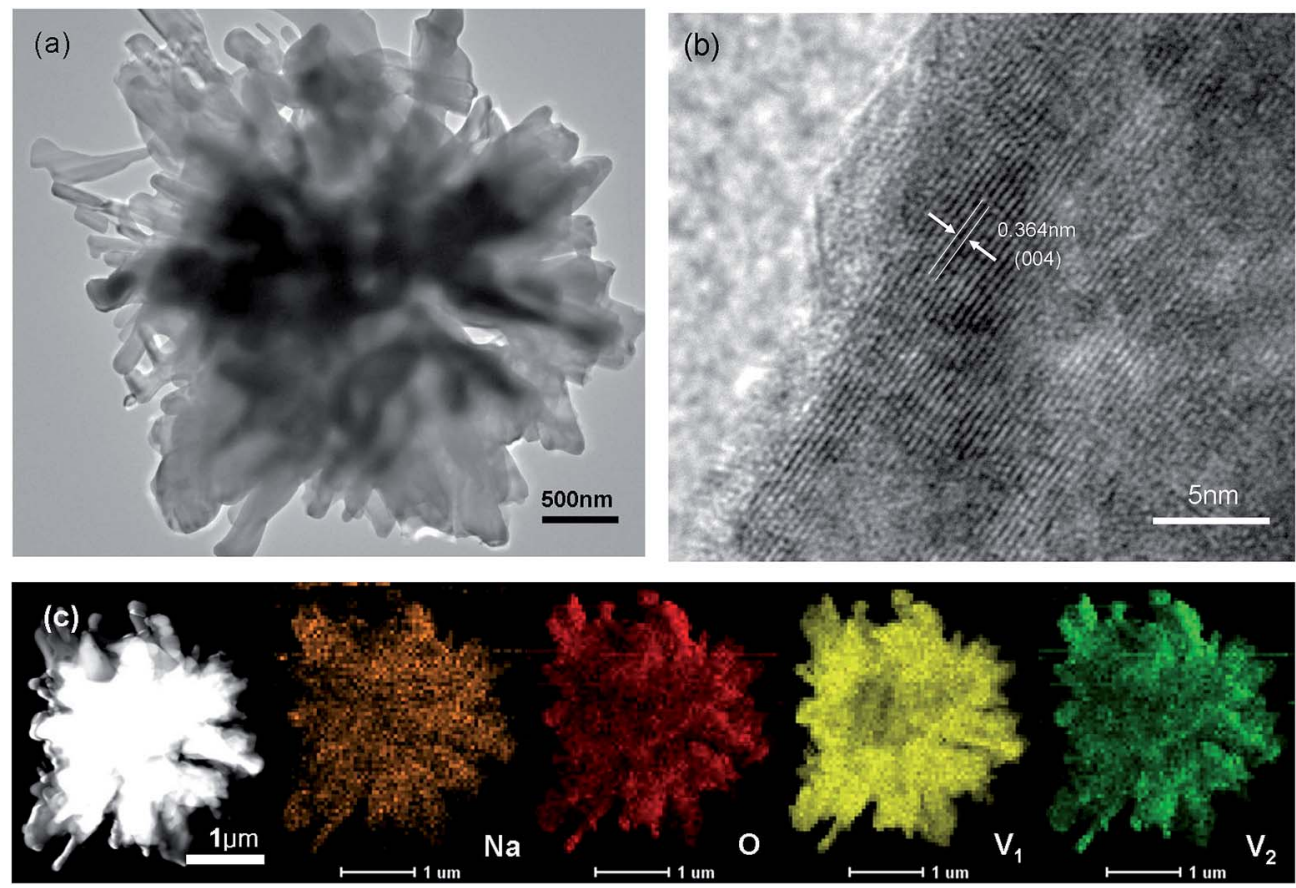

Fig. 3 TEM (a) and HRTEM (b) of $\mathrm{NaV}_{6} \mathrm{O}_{15}$ microflowers (c) mapping of $\mathrm{NaV}_{6} \mathrm{O}_{15}$ microflowers.

voltammetry curves of $\mathrm{NaV}_{6} \mathrm{O}_{15}$ microflowers (inset of Fig. 5a) at a scan rate of $0.05 \mathrm{mV} \mathrm{s}^{-1}$ from 1.5 to $4.0 \mathrm{~V}$, there are four plateaus at $3.25 \mathrm{~V}, 2.88 \mathrm{~V}, 2.49 \mathrm{~V}$ and $1.97 \mathrm{~V}$, indicating multistep intercalation of $\mathrm{Li}^{+}$ions and corresponding to $\mathrm{Li}$ contents of $0<x \leq 0.33,0.33<x \leq 0.66,0.66<x \leq 1.67$ and $1.67<x \leq 2.0$, respectively. ${ }^{32}$ Voltage profiles of first $\mathrm{Li}^{+}$ion intercalation plateau are relatively lower than those in subsequent intercalation processes (Fig. 5b). It might be due to successive and reversible phase transformations in the cathode materials during the insertion/extraction and stress/strain, whereas a large volume expansion in the first insertion result in large strain over-potential. ${ }^{33}$ The second discharge capacity is about 


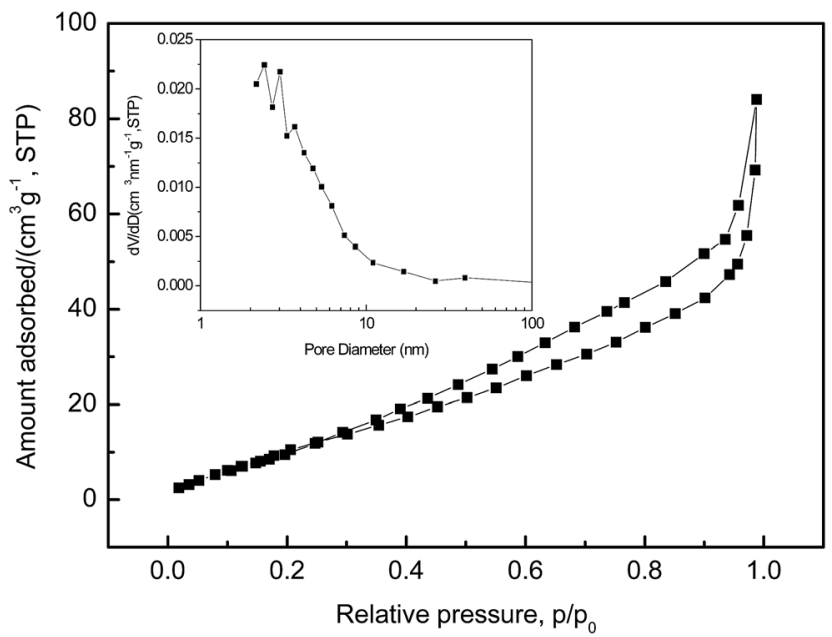

Fig. 4 Nitrogen adsorption-desorption isotherms and pore size distribution curves (in set) of $\mathrm{NaV}_{6} \mathrm{O}_{15}$ microflowers.

$280 \mathrm{~mA} \mathrm{~h} \mathrm{~g}{ }^{-1}$, which is higher than the first, revealing that a part of extra charge capacity is attributed to the extraction of $\mathrm{Na}^{+}$ions from the host material, which is similar to that of $\mathrm{Na}_{5} \mathrm{~V}_{12} \mathrm{O}_{32}{ }^{33}$ Therefore, more $\mathrm{Li}^{+}$can be inserted into the host material in the next curves. All of the charge-discharge profiles in Fig. 5b show similar multistep discharge/charge behaviors, suggesting a highly reversible process of $\mathrm{Li}^{+}$ion intercalation and deintercalation in $\mathrm{NaV}_{6} \mathrm{O}_{15}$ microflowers. After 50 cycles (Fig. 5c), $\mathrm{NaV}_{6} \mathrm{O}_{15}$ microflowers can maintain discharge capacities of $268 \mathrm{~mA} \mathrm{~h} \mathrm{~g}^{-1}$ at $100 \mathrm{~mA} \mathrm{~g}^{-1}$ with high coulombic efficiency of about $98 \%$ and high capacity retention of about $105 \%$. For comparison, electrochemical properties of $\mathrm{NaV}_{6} \mathrm{O}_{15}$ microflowers and other work with $\mathrm{Li}$ were summarized in Table 1. It can be seen that $\mathrm{NaV}_{6} \mathrm{O}_{15}$ micromicroflowers show outstanding electrochemical performance. Fig. $5 \mathrm{~d}$ shows rate performance of $\mathrm{NaV}_{6} \mathrm{O}_{15}$ microflowers at different current densities. At the current densities of $100 \mathrm{~mA} \mathrm{~g}^{-1}, 200 \mathrm{~mA} \mathrm{~g}^{-1}, 400 \mathrm{~mA} \mathrm{~g}^{-1}, 800$ $\mathrm{mA} \mathrm{g}^{-1}$ and $1600 \mathrm{~mA} \mathrm{~g}^{-1}, \mathrm{NaV}_{6} \mathrm{O}_{15}$ microflowers exhibit discharge capacities of $250 \mathrm{~mA} \mathrm{~h} \mathrm{~g}{ }^{-1}, 237 \mathrm{~mA} \mathrm{~h} \mathrm{~g}^{-1}, 195 \mathrm{~mA} \mathrm{~h}$ $\mathrm{g}^{-1}, 142 \mathrm{~mA} \mathrm{~h}^{-1}$ and $81.2 \mathrm{~mA} \mathrm{~h} \mathrm{~g}^{-1}$, respectively. When cycling at $100 \mathrm{~mA} \mathrm{~h} \mathrm{~g}^{-1}$ again, the discharge capacity remains at 233 $\mathrm{mA} \mathrm{h} \mathrm{g}{ }^{-1}$, which indicates $\mathrm{NaV}_{6} \mathrm{O}_{15}$ microflowers cathode remains stable after high rates.

To further understand the electrochemical kinetics, cyclic voltammetry curves of the electrodes at different voltage scan rates with $\mathrm{Li}$ were show in Fig. $6 \mathrm{a}$. The $\mathrm{Li}^{+}$diffusion coefficient $\left(D_{\mathrm{Li}}\right)$ of the material was calculated according to eqn (1).

$$
I_{\mathrm{p}}=2.69 \times 10^{5} n^{3 / 2} \mathrm{AD}^{1 / 2} v^{1 / 2} C
$$
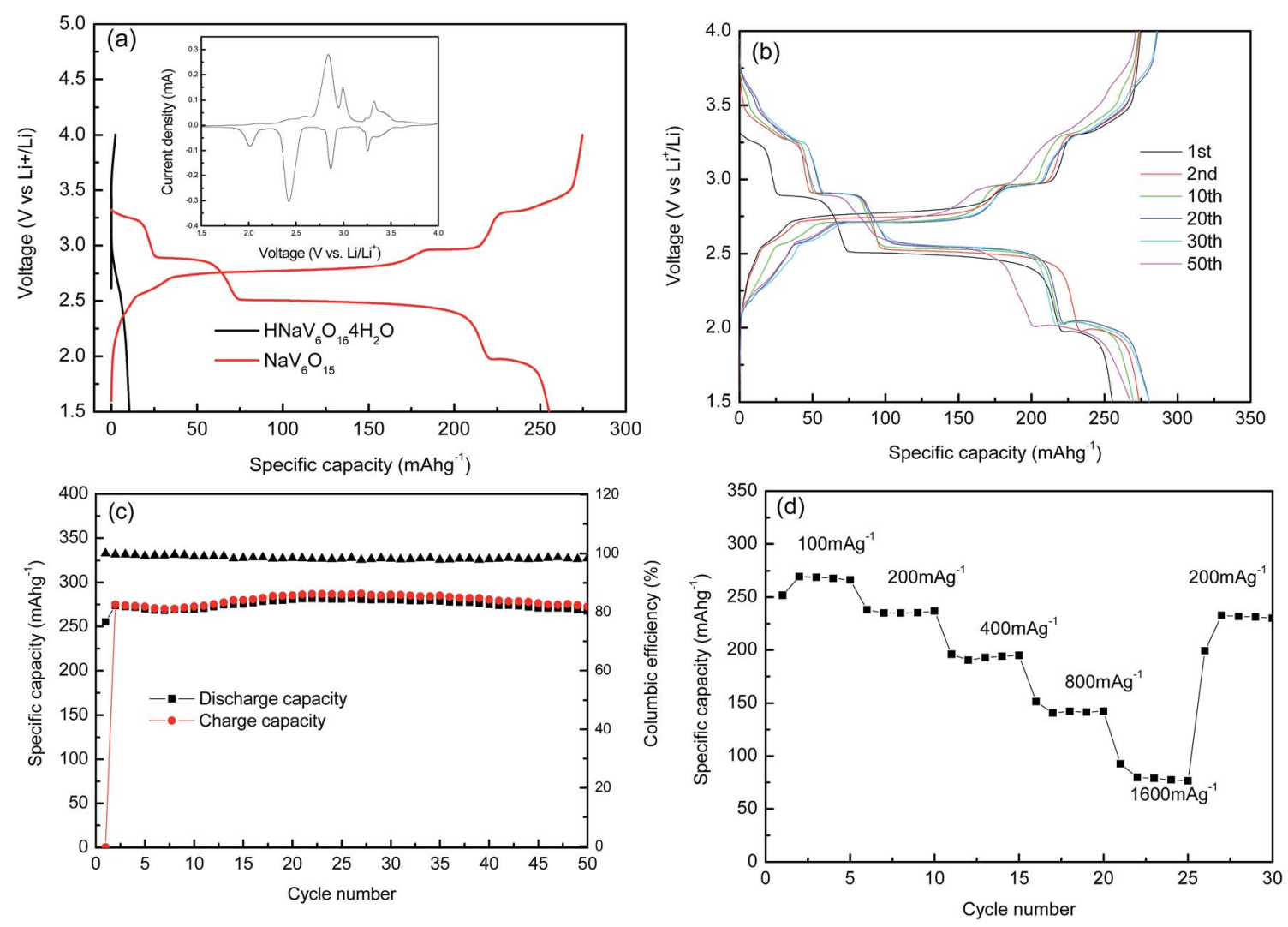

Fig. 5 (a) First charge-discharge profiles of $\mathrm{HNaV}_{6} \mathrm{O}_{16} \cdot 4 \mathrm{H}_{2} \mathrm{O}$ and $\mathrm{NaV}_{6} \mathrm{O}_{15}$ microflowers, the inset is $\mathrm{CV}$ curves of $\mathrm{NaV}_{6} \mathrm{O}_{15} / \mathrm{Li}(\mathrm{b})$ discharge/ charge profiles of the selected cycles at the current density of $100 \mathrm{~mA} \mathrm{~g}^{-1}$ (c) cycling performance of the electrodes at the current density of 100 $\mathrm{mA} \mathrm{g}^{-1}$ and the corresponding coulombic efficiency (d) rate performance tested at different current densities. 
Table 1 Comparison on electrochemical performance of $\mathrm{NaV}_{6} \mathrm{O}_{15}$ microflowers and other sodium vanadates as cathode material for LIBs

\begin{tabular}{|c|c|c|c|c|c|c|}
\hline Composition & $\begin{array}{l}\text { Current density } \\
\left(\mathrm{mA} \mathrm{g}^{-1}\right)\end{array}$ & 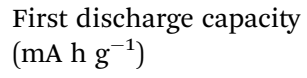 & $\begin{array}{l}\text { Cycle } \\
\text { numbers }\end{array}$ & $\begin{array}{l}\text { Capacity and retension } \\
\left(\mathrm{mA} \mathrm{h}^{-1}\right)\end{array}$ & $\begin{array}{l}\text { Li-ion } \\
\text { batteries }\end{array}$ & Ref. \\
\hline Rod-shaped $\beta-\mathrm{Na}_{0.33} \mathrm{~V}_{2} \mathrm{O}_{5}$ & 3.8 & 284 & 70 & $253(89 \%)$ & $\mathrm{Li}^{+} / \mathrm{Li}$ & 23 \\
\hline $\mathrm{Na}_{0.33} \mathrm{~V}_{2} \mathrm{O}_{5}$ nanosheets & 150 & 258 & 50 & $181(70.2 \%)$ & $\mathrm{Li}^{+} / \mathrm{Li}$ & 25 \\
\hline$\beta-\mathrm{Na}_{0.33} \mathrm{~V}_{2} \mathrm{O}_{5}$ nanorods & 60 & 224 & 50 & $182(81.3 \%)$ & $\mathrm{Li}^{+} / \mathrm{Li}$ & 28 \\
\hline $\mathrm{Na}_{0.33} \mathrm{~V}_{2} \mathrm{O}_{5}$ micro rod & 17 & 297 & 50 & $295(99 \%)$ & $\mathrm{Li}^{+} / \mathrm{Li}$ & 32 \\
\hline
\end{tabular}

( $n$, electron number per specific reaction (for $\mathrm{Li}^{+} n=1$ ); $A$, electrode surface area, about $0.64 \mathrm{~cm}^{2}$ in this work; $C$, Li ion concentration in the sample; $I_{\mathrm{p}}$, current intensity; $v$, scan rate). $I_{\mathrm{p}}$ varies linearly with $v^{1 / 2}$ as shown in Fig. $6 \mathrm{~b}$ and c. The lithium diffusion coefficients could be calculated by using eqn (1) (Fig. 6d). Li ions diffusion coefficient is about $5.6 \times 10^{-11}$ to 7.3 $\times 10^{-13} \mathrm{~cm}^{2} \mathrm{~s}^{-1}$, which is better than that of rod-shaped $\mathrm{Na}_{0.33} \mathrm{~V}_{2} \mathrm{O}_{5}{ }^{21}$ It may be attributed to porous structure of $\mathrm{NaV}_{6} \mathrm{O}_{15}$ microflowers, which could shorten the effective diffusion path and increase the window numbers for insertion and extraction of $\mathrm{Li}^{+}$. In addition, the $\mathrm{Li}$ ions diffusion coefficient $\left(D_{\mathrm{Li}}\right)$ of $\mathrm{NaV}_{6} \mathrm{O}_{15}$ microflowers showed a decrease during the discharge process, indicating that the diffusion of $\mathrm{Li}^{+}$in the electrode becomes more difficult, possibly resulted from the puckering $\left[\mathrm{V}_{6} \mathrm{O}_{15}\right]$ layers as well as the corresponding structural transformation.

The electrochemical performance of $\mathrm{NaV}_{6} \mathrm{O}_{15}$ microflowers as cathode material for $\mathrm{Na}$-ion batteries was also investigated. Fig. 7a shows charge-discharge profiles of $\mathrm{HNaV}_{6} \mathrm{O}_{16} \cdot 4 \mathrm{H}_{2} \mathrm{O}$ and $\mathrm{NaV}_{6} \mathrm{O}_{15}$ microflowers at a current density of $50 \mathrm{~mA} \mathrm{~g}{ }^{-1}$ with $\mathrm{Na}$ in the voltage range from $4 \mathrm{~V}$ to $1.5 \mathrm{~V}$. It also can be observed that the $\mathrm{HNaV}_{6} \mathrm{O}_{16} \cdot 4 \mathrm{H}_{2} \mathrm{O}$ microflowers electrode presents little electrochemical performance. $\mathrm{NaV}_{6} \mathrm{O}_{15}$ microflowers delivers a first discharge capacity of about $130 \mathrm{~mA} \mathrm{~h}$ $\mathrm{g}^{-1}$, which is also higher than that of $\mathrm{NaV}_{6} \mathrm{O}_{15}$ powders (Fig. S2b†). The cyclic voltammetry curves of $\mathrm{NaV}_{6} \mathrm{O}_{15}$
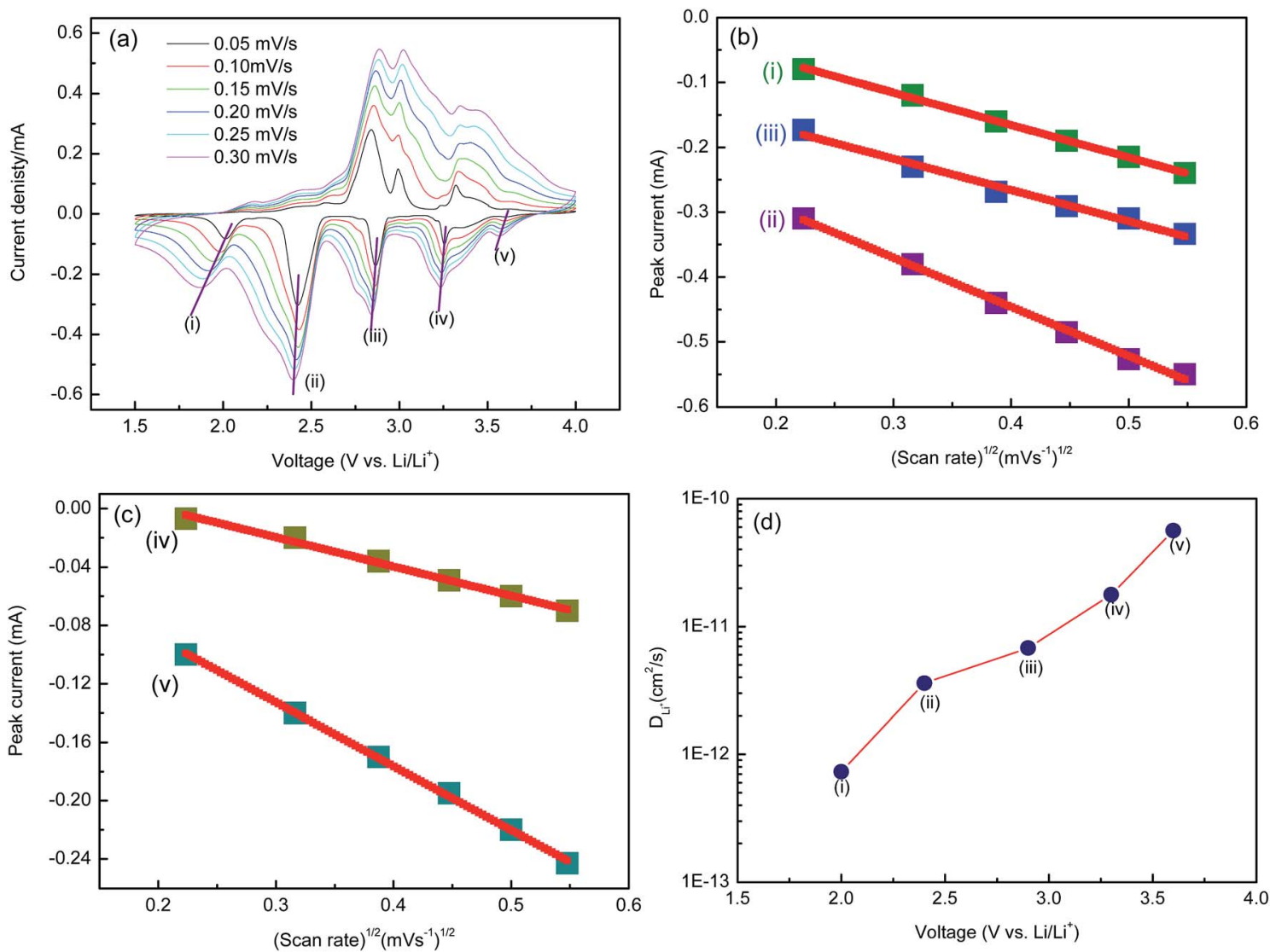

Fig. 6 (a) CV curves of the $\mathrm{NaV}_{6} \mathrm{O}_{15}$ microflowers at different voltage scan rates with $\mathrm{Li}$ (b) and (c) linear fitting of the $I_{\mathrm{p}}$ versus $v^{1 / 2}$ relationships for LIBs (d) diffusion coefficients of $\mathrm{Li}^{+}$in $\mathrm{NaV}_{6} \mathrm{O}_{15}$ microflowers at different charge states. 
microflowers (in inset of Fig. 7a) at a scan rate of $0.05 \mathrm{mV} \mathrm{s}^{-1}$ from 1.5 to $4.0 \mathrm{~V}$ shows three obvious anodic peaks at 2.08, 2.49 and $2.95 \mathrm{~V}$ and two cathodic peaks at 2.67 and $1.71 \mathrm{~V}$. Interestingly, $\mathrm{NaV}_{6} \mathrm{O}_{15}$ product shows different work plateaus between 4.0 and $1.5 \mathrm{~V}$ in the LIBs or SIBs, which can be understood by the complex structural transitions upon $\mathrm{Li}^{+} / \mathrm{Na}^{+}$ insertion with different ionic radius. ${ }^{34}$ In the subsequent charge-discharge processes, the discharge plateau at about $2.67 \mathrm{~V}$ in the first cycle disappears and the discharge capacity reduces to $115 \mathrm{~mA} \mathrm{~h} \mathrm{~g}{ }^{-1}$, which might be related to the structure rearrangement of $\mathrm{NaV}_{6} \mathrm{O}_{15}$ in the first $\mathrm{Na}$ ion intercalation. In the next few cycles, higher capacity can be attributed to the incomplete electrochemical reaction because of flowerlike morphology and inadequate contact with electrolyte.

After 50 cycles, the discharge capacity of $83 \mathrm{~mA} \mathrm{~h} \mathrm{~g}^{-1}$ is maintained with the retention of $64 \%$ and the coulombic efficiency of $82 \%$ (Fig. 7c). Compared to $\mathrm{NaV}_{6} \mathrm{O}_{15} / \mathrm{Li}$, good cycle performance of $\mathrm{NaV}_{6} \mathrm{O}_{15} / \mathrm{Li}$ may be due to that $\mathrm{Na}$ ions in $\mathrm{NaV}_{6} \mathrm{O}_{15}$ structure are thought to be immobile and to act as a pillar between the $\left[\mathrm{V}_{6} \mathrm{O}_{15}\right]$ layers, which prevent the structural collapse of $\mathrm{NaV}_{6} \mathrm{O}_{15}$ during charge/discharge cycling. In $\mathrm{NaV}_{6} \mathrm{O}_{15} / \mathrm{Na}, \mathrm{Na}^{+}$will not act as the pillar again and the extensive discharge depth to $1.5 \mathrm{~V}$ brings about a collapse of the crystallographic structure of the sample. ${ }^{35}$ Nevertheless, $\mathrm{NaV}_{6} \mathrm{O}_{15}$ microflowers shows good cycle performance when it was used as a cathode material for Na-ion batteries, superior over those reported in early literatures (Table 2).

Short cycling performance of $\mathrm{NaV}_{6} \mathrm{O}_{15}$ microflowers at different current rates from 50 to $800 \mathrm{~mA} \mathrm{~g}^{-1}$ is shown in Fig. $7 d$. The electrode presents good rate capability with high reversible discharge capabilities of $125 \mathrm{~mA} \mathrm{~h} \mathrm{~g}^{-1}, 112 \mathrm{~mA} \mathrm{~h}$ $\mathrm{g}^{-1}, 90 \mathrm{~mA} \mathrm{~h} \mathrm{~g}{ }^{-1}, 64 \mathrm{~mA} \mathrm{~h} \mathrm{~g}^{-1}$ and $38 \mathrm{~mA} \mathrm{~h} \mathrm{~g}^{-1}$ at the current densities of $50 \mathrm{~mA} \mathrm{~g}^{-1}, 100 \mathrm{~mA} \mathrm{~g}^{-1}, 200 \mathrm{~mA} \mathrm{~g}^{-1}, 400 \mathrm{~mA} \mathrm{~g}^{-1}$ and $800 \mathrm{~mA} \mathrm{~g}^{-1}$, respectively. In Fig. 8a, cyclic voltammetry in different scan rates was also utilized to determine the $\mathrm{Na}^{+}$diffusion coefficient $\left(D_{\mathrm{Na}}\right)$ of the sample, and $I_{\mathrm{p}}$ varies linearly with $v^{1 / 2}$ is shown in Fig. 8b. On this basis, one can calculate $\mathrm{Na}$ ions diffusion coefficients according to eqn (1) is about $1.37 \times 10^{-13}$ to $4.87 \times 10^{-13} \mathrm{~cm}^{2} \mathrm{~s}^{-1}$, which is close to the results of Electrochemical Impedance Spectroscopy (EIS). ${ }^{36,37}$ The result shows that the value of $D_{\mathrm{Na}}$ for $\mathrm{NaV}_{6} \mathrm{O}_{15}$ sample obtained is higher than that of olivine $\mathrm{NaFePO}_{4}\left(8.7 \times 10^{-17} \mathrm{~cm}^{2} \mathrm{~s}^{-1}\right){ }^{38}$ which shows potential application as a cathode candidate for NIBs with high performance.
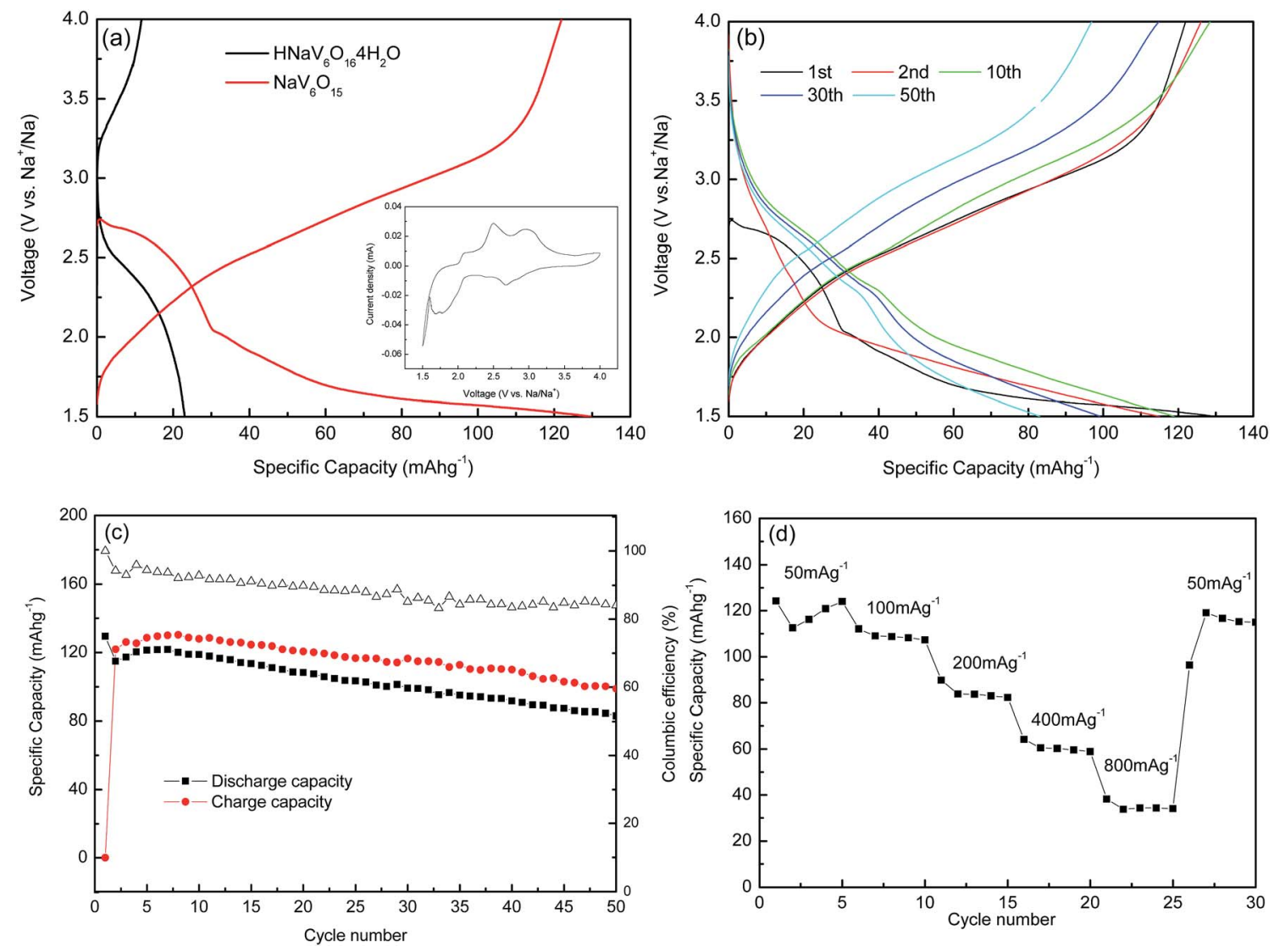

Fig. 7 (a) First charge-discharge profiles of $\mathrm{HNaV}_{6} \mathrm{O}_{16} \cdot 4 \mathrm{H}_{2} \mathrm{O}$ and $\mathrm{NaV}_{6} \mathrm{O}_{15}$ microflowers, the inset is $\mathrm{CV}$ curves of $\mathrm{NaV} \mathrm{O}_{15} / \mathrm{Na}$ (b) discharge/ charge profiles of the selected cycles at the current density of $50 \mathrm{~mA} \mathrm{~g}^{-1}$ (c) cycling performance of $\mathrm{NaV}_{6} \mathrm{O}_{15}$ microflowers at the current density of $50 \mathrm{~mA} \mathrm{~g}^{-1}$ and the corresponding coulombic efficiency; (d) rate performance tested at different current densities. 
Table 2 Comparison on electrochemical performance of $\mathrm{NaV}_{6} \mathrm{O}_{15}$ microflowers and other sodium vanadates as cathode material for NIBs

\begin{tabular}{|c|c|c|c|c|c|c|}
\hline Composition & $\begin{array}{l}\text { Current density } \\
\left(\mathrm{mA} \mathrm{g}^{-1}\right)\end{array}$ & $\begin{array}{l}\text { First discharge } \\
\text { capacity }\left(\mathrm{mA} \mathrm{h} \mathrm{g}^{-1}\right)\end{array}$ & $\begin{array}{l}\text { Cycle } \\
\text { numbers }\end{array}$ & $\begin{array}{l}\text { Capacity and retension } \\
\left(\mathrm{mA} \mathrm{h} \mathrm{g}^{-1}\right)\end{array}$ & $\begin{array}{l}\text { Na-ion } \\
\text { batteries }\end{array}$ & Ref. \\
\hline $\mathrm{NaV}_{6} \mathrm{O}_{15}$ nanoflakes & 15 & 148 & 30 & $136(92.2 \%)$ & $\mathrm{Na}^{+/} \mathrm{Na}$ & 27 \\
\hline $\mathrm{NaV}_{6} \mathrm{O}_{15}$ nanoplates & 50 & 116 & 30 & $63.8(55 \%)$ & $\mathrm{Na}^{+/} \mathrm{Na}$ & 29 \\
\hline $\mathrm{NaV}_{6} \mathrm{O}_{15}$ nanorods & 50 & 106 & 30 & $75(71 \%)$ & $\mathrm{Na}^{+/} \mathrm{Na}$ & 35 \\
\hline $\mathrm{NaV}_{6} \mathrm{O}_{15}$ nanorods & 50 & 134 & 20 & $96.5(72 \%)$ & $\mathrm{Na}^{+/} \mathrm{Na}$ & 36 \\
\hline $\mathrm{Na}_{0.33} \mathrm{~V}_{2} \mathrm{O}_{5}$ nanosheets & 20 & 188.4 & 50 & $97.8(51.9 \%)$ & $\mathrm{Na}^{+/} \mathrm{Na}$ & 37 \\
\hline \multirow[t]{2}{*}{$\mathrm{NaV}_{6} \mathrm{O}_{15}$ nanoflowers } & 50 & 130 & 30 & $100(77 \%)$ & $\mathrm{Na}^{+/} \mathrm{Na}$ & This work \\
\hline & & & 50 & $83(64 \%)$ & & \\
\hline
\end{tabular}
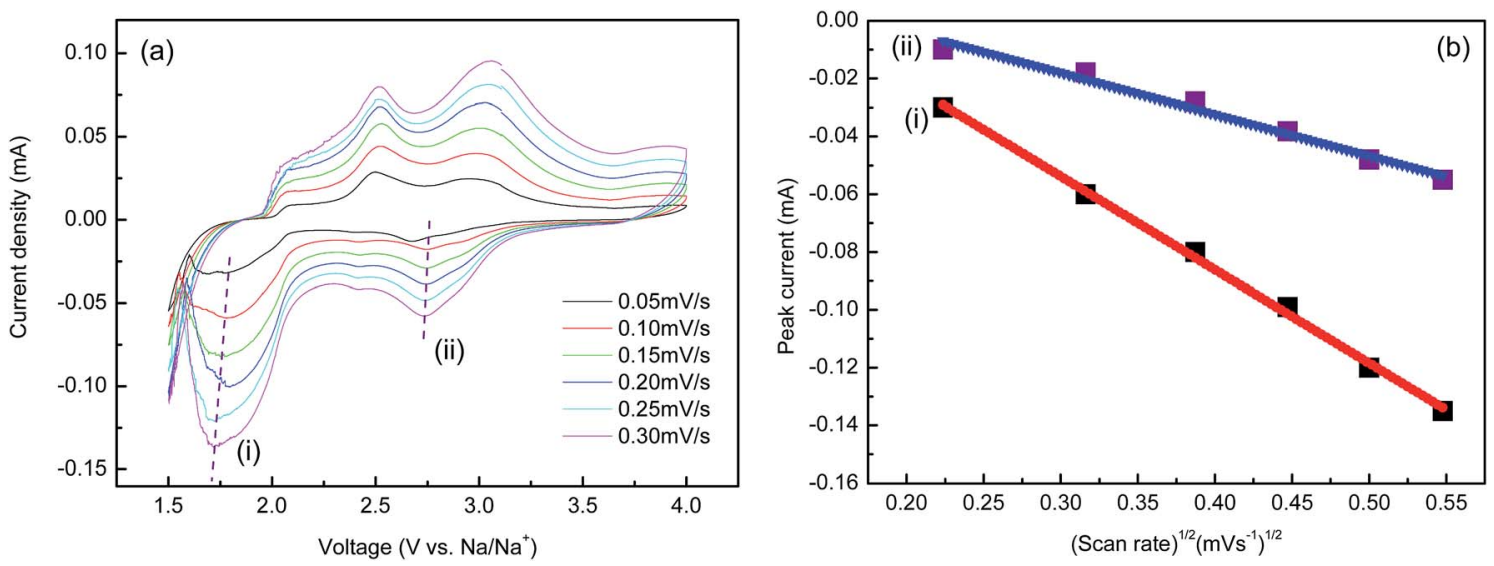

Fig. 8 (a) $\mathrm{CV}$ curves of $\mathrm{NaV}_{6} \mathrm{O}_{15}$ microflowers at different voltage scan rates with $\mathrm{Na}$ (b) linear fitting of the $I_{\mathrm{p}}$ versus $v^{1 / 2}$ relationships.

\section{Conclusions}

In summary, $\mathrm{NaV}_{6} \mathrm{O}_{15}$ microflowers have been successfully synthesized using a simple hydrothermal method with subsequent annealing treatment. The as-synthesized $\mathrm{NaV}_{6} \mathrm{O}_{15}$ microflowers are investigated as cathodes for both LIBs and SIBs, which exhibited good electrochemical storage performance. According to cyclic voltammetry analysis at different voltage scan rates, $\mathrm{Li} / \mathrm{Na}$, the $\mathrm{Li} / \mathrm{Na}$ ions diffusion coefficients is about $10^{-11}$ and $10^{-13} \mathrm{~cm}^{2} \mathrm{~s}^{-1}$, respectively. High Li/Na ions diffusion coefficients would be responsible for remarkable electrochemical performance of $\mathrm{NaV}_{6} \mathrm{O}_{15}$ microflowers.

\section{Acknowledgements}

This work was supported Foundation of state Key Laboratory of high effciency Utilization of Coal and Green Chemical Engineering (Grant No. 2016-19), initial funding for top level talents of Shenyang University of Technology and Nature Science Fund of Liaoning province (No. 20170540671).

\section{References}

1 D. X. Wang, Q. Liu, C. J. Chen, M. L. Li, X. Meng, X. F. Bei, Y. J. Wei, Y. H. Huang, F. Du and C. Z. Wang, ACS Appl. Mater. Interfaces, 2016, 8, 2238.

2 Y. T. Han, X. Wu, Y. L. Ma, L. H. Gong, F. Y. Qu and H. J. Fan, CrystEngComm, 2011, 13, 3506.
3 L. N. Gao, F. Y. Qu and X. Wu, J. Mater. Chem. A, 2014, 2, 7367-7372.

4 N. Chen, Y. Gao, M. N. Zhang, X. Meng, C. Z. Wang, Y. J. Wei, F. Du and G. Chen, Chem.-Eur. J., 2016, 22, 7248.

5 Y. Liu, Y. Jiao, H. Y. Zhou, X. Yu, F. Y. Qu and X. Wu, NanoMicro Lett., 2015, 7, 12.

6 L. N. Gao, X. F. Wang, Z. Xie, W. F. Song, L. J. Wang, X. Wu, F. Y. Qu, D. Chen and G. Z. Shen, J. Mater. Chem. A, 2014, 2, 7167-7173.

7 M. L. Li, Y. Gao, N. Chen, X. Meng, C. Z. Wang, Y. Q. Zhang, D. Zhang, Y. J. Wei, F. Du and G. Chen, Chem.-Eur. J., 2016, 22, 11405.

8 J. Wei, F. Hu, S. Y. Yao, Z. P. Sun and X. Wu, Mater. Res. Bull., 2017, 93, 303.

9 X. H. Xiong, G. H. Wang, Y. W. Lin, Y. Wang, X. Ou, F. H. Zheng, C. H. Yang, J. H. Wang and M. L. Liu, ACS Nano, 2016, 10, 10953.

10 X. Ou, X. H. Xiong, F. H. Zheng, C. H. Yang, Z. H. Lin, R. Z. Hu, C. Jin, Y. Chen and M. L. Liu, J. Power Sources, 2016, 325, 410.

11 Y. Y. Zhao, Z. X. Wei, Q. Pang, Y. J. Wei, Y. M. Cai, Q. Fu, F. Du, A. Sarapulova, H. Ehrenberg and B. B. Liu, ACS Appl. Mater. Interfaces, 2017, 9, 4709.

12 Z. J. Zhang, Y. X. Wang, S. L. Chou, H. J. Li, H. K. Liu and J. Z. Wang, J. Power Sources, 2015, 280, 107.

13 N. Yabuuchi, K. Kubota, M. Dahbi and S. Komaba, Chem. Rev., 2014, 114, 11636. 
14 Y. J. Fang, L. F. Xiao, J. F. Qian, X. P. Ai, H. X. Yang and Y. L. Cao, Nano Lett., 2014, 14, 3539.

15 D. Z. Kong, C. W. Cheng, Y. Wang, B. Liu, Z. X. Huang and H. Y. Yang, J. Mater. Chem. A, 2016, 4, 11800.

16 A. Q. Pan, J. G. Zhang, Z. M. Nie, G. Z. Cao, B. W. Arey, G. S. Li, S. Q. Liang and J. Liu, J. Mater. Chem., 2010, 20, 9193.

17 M. Winter, J. O. Besenhard, M. E. Spahr and P. Novák, Adv. Mater., 1998, 10, 725.

18 H. N. He, G. H. Jin, H. Y. Wang, X. B. Huang, Z. H. Chen, D. Sun and Y. G. Tang, J. Mater. Chem. A, 2014, 2, 3563.

19 H. N. He, Z. G. Shang, X. B. Huang, S. Tan, D. Sun, G. Q. Xu, Y. G. Tang and H. Y. Wang, J. Electrochem. Soc., 2016, 163, A2349.

20 G. Q. Xu, H. N. He, H. Wan, R. H. Liu, X. G. Zeng, D. Sun, X. B. Huang and H. Y. Wang, J. Appl. Electrochem., 2016, 46, 879 .

21 J. K. Kim, B. Senthilkumar, H. S. Sun, J. H. Kim, M. F. Chi and Y. Kim, ACS Appl. Mater. Interfaces, 2015, 12, 7025.

22 S. A. Bach, J. Electrochem. Soc., 1990, 137, 1042.

23 S. Q. Liang, J. Zhou, G. Z. Fang, C. Zhang, J. Wu, Y. Tang and A. Q. Pan, Electrochim. Acta, 2014, 130, 119.

24 D. Sun, G. H. Jin, H. Y. Wang, P. Liu, Y. Ren, Y. F. Jiang, Y. G. Tang and X. B. Huang, J. Mater. Chem. A, 2014, 2, 12999.

25 Y. K. Lu, J. Wu, J. Liu, M. Lei, S. S. Tang, P. J. Lu, L. Y. Yang, H. R. Yang and Q. Yang, ACS Appl. Mater. Interfaces, 2015, 7(31), 17433.

26 Q. G. Tan, Y. P. Wang, Y. Tang, X. P. Tan, S. Q. Liang and G. Z. Cao, CrystEngComm, 2015, 17, 4774.
27 D. L. Jiang, H. Wang, G. P. Li, G. Q. Li, X. Z. Lan, M. H. Abib, Z. P Zhang and J. G. Yang, J. Electrochem. Soc., 2015, 162(4), A697.

28 P. P. Wang, Y. X. Cheng, F. X. Ma, Y. Li and L. Zhen, RSC Adv., 2016, 6, 105833.

29 H. N. He, X. G. Zeng, H. Y. Wang, N. Chen, D. Sun, Y. G. Tang, X. B. Huang and Y. F. Pana, J. Electrochem. Soc., 2015, 162(1), A39.

30 M. S. Park, Y. M. Kang, G. X. Wang, S. X. Dou and H. K. Liu, Adv. Funct. Mater., 2008, 18, 455.

31 Y. Liu and X. G. Zhang, Electrochim. Acta, 2009, 54, 4180.

32 I. Seo, G. C. H. Wang, J. K. Kim and Y. Kim, Electrochim. Acta, 2016, 193, 160.

33 Y. H. Cao, D. Fang, C. Wang, L. C. Li, W. L. Xu, Z. P. Luo, X. Q. Liu, C. X. Xiong and S. Q. Liu, RSC Adv., 2015, 5, 42955.

34 S. L. Zheng, X. Y. Wang, H. Yan, H. Du and Y. Zhang, Mater. Res. Bull., 2016, 81, 10.

35 H. M. Liu, H. S. Zhou, L. P. Chen, Z. F. Tang and W. S. Yang, J. Power Sources, 2011, 196, 814.

36 X. Y. Wang, Q. Liu, H. Wang, D. L. Jiang, Y. J. Chang, T. Zhang, B. Zhang, H. H. Mou and Y. Jiang, J. Mater. Sci., 2016, 51, 8986.

37 Y. K. Lu, N. Su, L. Z. Cheng, J. Liu, L. Y. Yang, H. R. Yang, Q. Yang, S. T. Li, J. Min and M. Lei, Mater. Lett., 2016, 183, 346.

38 Y. Zhu, Y. Xu, Y. Liu, C. Luo and C. Wang, Nanoscale, 2013, 5(2), 780. 